Article

\title{
Embodiment Analysis for Greenhouse Gas Emissions by Chinese Economy Based on Global Thermodynamic Potentials
}

\author{
Bo Zhang ${ }^{1,2, *}$, Suping Peng ${ }^{1}$, Xiangyang $\mathrm{Xu}^{2}$ and Lijie Wang ${ }^{2, *}$
}

1 State Key Laboratory of Coal Resources and Safe Mining, China University of Mining \& Technology (Beijing), Beijing 100083, China; E-Mail: psp@cumtb.edu.cn

2 School of Management, China University of Mining \& Technology (Beijing), Beijing 100083, China; E-Mail: cleanwater96@163.com

* Authors to whom correspondence should be addressed; E-Mails: zhb@pku.edu.cn (B.Z.); wanglijie.prof@263.net (L.W.); Tel./Fax: +86-010-62339316.

Received: 1 August 2011; in revised form: 8 October 2011 / Accepted: 31 October 2011 / Published: 4 November 2011

\begin{abstract}
This paper considers the Global Thermodynamic Potential (GTP) indicator to perform a unified assessment of greenhouse gas (GHG) emissions, and to systematically reveal the emission embodiment in the production, consumption, and international trade of the Chinese economy in 2007 as the most recent year available with input-output table and updated inventory data. The results show that the estimated total direct GHG emissions by the Chinese economy in 2007 amount to $10,657.5 \mathrm{Mt} \mathrm{CO}_{2}$-eq by the GTPs with $40.6 \%$ from $\mathrm{CH}_{4}$ emissions in magnitude of the same importance as $\mathrm{CO}_{2}$ emissions. The five sectors of Electric Power/Steam and Hot Water Production and Supply, Smelting and Pressing of Ferrous and Nonferrous Metals, Nonmetal Mineral Products, Agriculture, and Coal Mining and Dressing, are responsible for $83.3 \%$ of the total GHG emissions with different emission structures. The demands of coal and coal-electricity determine the structure of emission embodiment to an essential extent. The Construction sector holds the top GHG emissions embodied in both domestic production and domestic consumption. The GHG emission embodied in gross capital formation is more than those in other components of final demand characterized by extensive investment and limited household consumption. China is a net exporter of embodied GHG emissions, with a remarkable share of direct emission induced by international trade, such as textile products, industrial raw materials, and primary machinery and equipment products exports. The fractions of $\mathrm{CH}_{4}$ in the component of embodied GHG emissions in the final demand are much greater than those
\end{abstract}


fractions calculated by the Global Warming Potentials, which highlight the importance of $\mathrm{CH}_{4}$ emissions for the case of China and indicate the essential effect of $\mathrm{CH}_{4}$ emissions on global climate change. To understand the full context to achieve GHG emission mitigation, this study provides a new insight to address China's GHG emissions status and hidden emission information induced by the final demand to the related policy-makers.

Keywords: exergy; input-output embodiment analysis; greenhouse gas emissions in China

\section{Introduction}

China has been considered as the largest carbon dioxide emitter in the World since 2007 [1]. Certainly, along with the consumption structure upgrade and urbanization in the future, the amount of GHG emissions in China is expected to increase further [2]. All these facts reflect the unprecedented emergency of GHG emission control and mitigation in the Chinese economy. Before any effective mitigation measures can be undertaken, a clear understanding of the current emission status and situation must be obtained first. In addition to the direct GHG emission mitigation for prominent industries, there is also a need to make policies by identifying the consumption-side mitigation polices that the emissions induced by the final demand $[3,4]$.

To quantify and evaluate GHG emission patterns and structure for a society, only a small number of economic sectors considered are limited to reflect more detailed and complex network structure. As a commonly available economic model to describe the complicated network relationship and structure of economic sectors, input-output model originally introduced by Leontief to analyze the interdependence of economic sectors has been rigorously extended and widely used in the sectoral embodiment analysis of GHG emissions in general (e.g., [4-6]). The concept of embodied emissions facilitates a deeper appreciation of the sectoral total emission requirements in terms of both the direct, visible and indirect, hidden emission cost, which appreciates the industry-specific features as well as the holistic societal structure. Extensive studies have been made to perform input-output analysis of GHG emissions in China, mainly focusing on $\mathrm{CO}_{2}$ emission embodiment (e.g., [7-16]). The unique official GHG emission inventory of China pointed out that $\mathrm{CH}_{4}$ emissions accounted for $19.4 \%$ of the total national-wide GHG emissions in terms of $\mathrm{CO}_{2}, \mathrm{CH}_{4}$ and $\mathrm{N}_{2} \mathrm{O}$ in 1994 [17]. Zhang and Chen [18] reported that the total $\mathrm{CH}_{4}$ emission of 26 industrial sectors by Chinese economy in 2007 is 39,592.7 $\mathrm{Gg}$ or $989.8 \mathrm{Mt} \mathrm{CO}_{2}$-eq by the lower referred IPCC global warming potential (GWP), in magnitude of about one sixth of China's $\mathrm{CO}_{2}$ emission from fuel combustion and greater than $\mathrm{CO}_{2}$ emissions from fuel combustion of many economically developed countries such as UK, Canada, and Germany. Only considering the $\mathrm{CO}_{2}$ emissions cannot reflect the real situation and full-scale picture of China's GHG emissions, especially in terms of sectoral structure and embodiment in final consumption and international trade [3]. Prominent studies about the embodiment of China's GHG emissions were systematically conducted by Chen and co-workers in their multi-scale ecological input-output analysis (IOA) of environmental emissions. In his doctoral dissertation Zhou [19] presented two sets of databases for embodiment intensity of GHG emissions, one for the Chinese economy in 1992 under the Material Product System (MPS) for planning economies of the Soviet 
socialist style and another for the Chinese economy in 2002 under the System of National Accounts (SNA) for marketing economies; Chen et al. [20] and Chen and Chen [21] afterwards accounted for the GHG emission embodiment in the Chinese economy in 2005 and 2007, respectively; Chen and Chen [22] simulated the GHG emission embodiment in the global economy 2000, referring to Chinese economy; in particular, Chen and Zhang [3] provided a concrete GHG emission inventory of Chinese economy 2007 to cover all the main anthropogenic sources of $\mathrm{CO}_{2}, \mathrm{CH}_{4}$ and $\mathrm{N}_{2} \mathrm{O}$, and presented a detailed input-output analysis for the GHG emission embodiment in final consumption and international trade. These studies have contributed to direct and indirect GHG emission estimation and related assessment for mitigation potential in China.

It is worth noting that in order to account for the equivalent $\mathrm{CO}_{2}\left(\mathrm{CO}_{2}\right.$-eq.) emissions, one typical scheme has been applied extensively in most previous studies, which is based on the commonly referred IPCC Global Warming Potentials (GWPs) over a time horizon of 100 years. In fact, the indicator of GWP based on simplified radiation models has various GWP values over different time horizons even for the same greenhouse gas [23]. Furthermore, the GWP indicator is merely one kind of evaluation method for GHG emissions. There are several other typical equivalent indicators based on different evaluation models to assess GHG emissions. The Global Thermodynamic Potential (GTP) indicator derived from chemical exergy model is one option, which has been gradually accepted as a unified measure for GHG emissions in recent years.

Defined as the maximum amount of work which can be produced by a system as it comes to equilibrium with a reference environment [24-26] to represent the physical deviation between the system and the reference environment, the concept of exergy based on the first two laws of thermodynamics provides us with an ideal unified measure for various environmental emissions as a consistent and objective assessment [27-32]. All emissions have definable, calculable and additive exergy contents with respect to the defined reference environment. Wall [24,33] further suggested exergy as a suitable measure of environmental impact of waste emissions and asserted that all utilization of resources and disposal of waste products affect nature and the effect is strongly related to the amount of exergy in the utilized resource or the disposed waste [34]. Ayres [35] stated that non-zero exergy can be regarded as the potential for doing harm by driving uncontrolled reaction in the environment. Rosen and his colleagues [25,27,36-39] have illustrated the meaning of exergy to environmental emissions. The total exergy of an emission is the physicochemical work absorbed by the environment in order to equilibrate the substances of the emission with the standard environment [31]. In other words, the exergy emitted represents a driving potential, hence causing environmental damage, particularly when released on a large scale into the environment $[27,33,40]$. With the global reference environment model initiated by Szargut [28], exergy has been taken as a physical indicator for the potential environmental effect on the biophysical earth in general and geochemical sphere in particular [28,29]. Exergy-based unifying assessment for the environmental emissions of typical social sectors [30,34,41] and social systems [42-44] has been extensively performed in recent years. Furthermore, the indicator of Global Thermodynamic Potentials based on the chemical exergy model has been used to compare the thermodynamic departure between the GHG emission and its surrounding relative to carbon dioxide in terms of carbon dioxide equivalents $[18,21,22,44]$.

Rational and significant evaluation for environmental emissions from different angles of view can be carried out based on single or multi-disciplinary evaluation methods [45]. Besides the emission 
embodiment based on the GWPs, further research coupled with other emission equivalent evaluation will provide a more sound theoretical basis for making and analyzing GHG emission embodiment for the Chinese economy. The target of this paper is to consider the Global Thermodynamic Potential indicator to perform a unified GTP-based emission assessment of the three most commonly considered GHGs, i.e., $\mathrm{CO}_{2}, \mathrm{CH}_{4}$ and $\mathrm{N}_{2} \mathrm{O}$, and to systematically reveal the emission embodiment in production, consumption, and international trade of the Chinese economy in 2007 as the most recent year with available input-output tables and updated inventory data.

The main context of this paper is organized as follows. In Section 2, we describe the GTP calculation methodology, input-output analysis, and data sources. Section 3 and Section 4 present the direct GHG emission and embodied GHG emission analysis, respectively, and corresponding analysis results are discussed. Finally, main conclusions will be drawn in Section 5.

\section{Methodology and Data Sources}

\subsection{Global Thermodynamic Potentials}

Due to the emissions being in disequilibrium with the reference environment, GHG emissions have an exergy value. As to the emission account for the society system as a macro-economy, it is reasonable to adopt a global standard environment model to resemble the atmosphere, the ocean and the Earth's upper crust with average geophysical chemical characteristics as the reference environment $[28,46]$. The chemical exergy of an emission reflects the deviation in chemical composition from the reference environment, and is the most important contribution to its exergetic value. Therefore, only chemical exergy is considered in this study. The standard chemical exergy values of the basic chemical compound can be readily obtained from Szargut [28] and then the Global Thermodynamic Potential (GTP) of GHG emissions relative to that of carbon dioxide (whose GTP is by definition 1) can be calculated. Detailed exergy factors and corresponding GTPs of $\mathrm{CO}_{2}, \mathrm{CH}_{4}$ and $\mathrm{N}_{2} \mathrm{O}$ are listed in Table 1. From the exergetic perspectives, higher exergetic value or GTP of the emission reflects the larger deviation in chemical composition from the reference environment and indicates its essential effect on global climate change.

Table 1. Global Thermodynamic Potentials (GTPs) of $\mathrm{CO}_{2}, \mathrm{CH}_{4}$ and $\mathrm{N}_{2} \mathrm{O}$.

\begin{tabular}{ccc}
\hline Emission Type & Exergy Factors $(\mathbf{k J} / \mathbf{g})$ & GTPs \\
\hline Carbon dioxide $\left(\mathrm{CO}_{2}\right)$ & 0.45 & 1 \\
Methane $\left(\mathrm{CH}_{4}\right)$ & 51.98 & 115.51 \\
Nitrous oxide $\left(\mathrm{N}_{2} \mathrm{O}\right)$ & 2.40 & 5.33 \\
\hline
\end{tabular}

\subsection{Input-Output Analysis and Data Sources}

The algorithms for input-output analysis and basic embodied emissions have been introduced in detail in [18]. Briefly, the emissions generated in both homeland and imports induced by the final demand can be obtained by pre-multiplying the final demand by the row vector of the embodied emission intensity (the multiplication of the direct emission intensity matrix and the well-known Leontief inverse matrix). Then, the embodied emission induced by each category of final demand, such 
as household consumption, government consumption, and capital investment can be calculated. The emission embodied in domestic production, denoted by EEP, is the emission induced by the final demand minus the emission embodied in imports. The emission embodied in exports (EEE) or imports (EEI; Emission avoided by import in deed) can be calculated by multiplying the embodied emission intensity in terms of a row vector with the exported or imported products (monetary value). The emission embodied in domestic consumption, EEC, represents the production-based emission excluding the emission embodied in exports but including the emission embodied in imports. Combining the embodied emissions from exports and imports or domestic production and domestic consumption, the net embodied emission of international trade balance (EEB) can be obtained. A positive EEB means the net embodied emission exporter or a trade surplus of embodied emission, and negative means the net embodied emission importer or deficit. Concrete elaboration of the input-output model and indicator description can be referred to [18].

The Chinese input-output (IO) table of 2007, covering 42 sectors in total [47], is the most recently available IO table. To comply with relevant environmental resources and energy statistics data, Chen and Zhang [3] merged these 42 sectors into 26 sectors to compose a revised input-output table for the 2007 Chinese economy. This paper adopts this aggregated IO table directly with sector information listed in Table 2.

Table 2. Aggregated sectors for input-output analysis.

\begin{tabular}{cl}
\hline Code & \\
\hline 1 & Farming, Forestry, Animal Husbandry, Fishery and Water Conservancy (Agriculture) \\
2 & Coal Mining and Dressing \\
3 & Petroleum and Natural Gas Extraction \\
4 & Ferrous and Nonferrous Metals Mining and Dressing \\
5 & Nonmetal and Other Minerals Mining and Dressing \\
6 & Food Processing, Food Production, Beverage Production, Tobacco Processing \\
7 & Textile \\
8 & Garments and Other Fiber Products, Leather, Furs, Down and Related Products \\
9 & Timber Processing, Bamboo, Cane, Palm and Straw Products, Furniture Manufacturing \\
& Papermaking and Paper Products, Printing and Record Medium Reproduction, Cultural, \\
10 & Educational and Sports Articles \\
11 & Petroleum Processing and Coking, Gas Production and Supply \\
12 & Raw Chemical Materials and Chemical Products, Medical and Pharmaceutical Products, \\
& Chemical Fiber, Rubber Products, Plastic Products (Chemical Products Related Industry) \\
13 & Nonmetal Mineral Products \\
14 & Smelting and Pressing of Ferrous and Nonferrous Metals \\
16 & Metal Products \\
17 & Ordinary Machinery, Equipment for Special Purpose \\
18 & Electric Equipment and Machinery \\
19 & Electronic and Telecommunications Equipment \\
20 & Instruments, Meters Cultural and Office Machinery \\
21 & Other Industrial Activities \\
\hline
\end{tabular}


Table 2. Cont.

\begin{tabular}{cl}
\hline Code & \multicolumn{1}{c}{ Sector } \\
\hline 22 & Electric Power/Steam and Hot Water Production and Supply \\
23 & Construction \\
24 & Transport, Storage, Postal and Telecommunications Services \\
25 & Wholesale, Retail Trade, Hotels, Catering Service \\
26 & Other Service Activities \\
\hline
\end{tabular}

For greenhouse gas emissions by the Chinese economy in 2007, an updated concrete inventory covering three of the most concerned types, i.e., $\mathrm{CO}_{2}, \mathrm{CH}_{4}$, and $\mathrm{N}_{2} \mathrm{O}$, has been compiled by Zhang [48]. Using his inventory data, corresponding equivalent values of the three main greenhouse gases by sector can be gained to make a unified assessment.

\section{Direct GHG Emissions}

Based on the Global Thermodynamic Potentials $\left(\mathrm{CO}_{2}: \mathrm{CH}_{4}: \mathrm{N}_{2} \mathrm{O}=1: 115.51: 5.33\right)$, direct GHG emissions by emission type and sector category are calculated and shown in Table 3 . The estimated total direct GHG emissions by the Chinese economy in 2007 amount to $10,657.5 \mathrm{Mt} \mathrm{CO}_{2}$-eq, of which the $\mathrm{CO}_{2}$ emission contributes $6324.4 \mathrm{Mt}, \mathrm{CH}_{4} 4328.8 \mathrm{Mt}$, and $\mathrm{N}_{2} \mathrm{O} 4.25 \mathrm{Mt}$. As to the emission structure, $\mathrm{CO}_{2}$ emissions from fuel combustion comprise $44.34 \%, \mathrm{CO}_{2}$ emissions from industrial process $15.00 \%, \mathrm{CH}_{4}$ emissions $40.62 \%$ and $\mathrm{N}_{2} \mathrm{O}$ emissions $0.04 \%$. The $\mathrm{CH}_{4}$ emissions are in magnitude of the same importance as the $\mathrm{CO}_{2}$ emissions.

Table 3. GTP-based GHG emissions by Chinese economy 2007 by sector ( $\mathrm{Mt} \mathrm{CO}_{2}$-eq).

\begin{tabular}{cccccc}
\hline Sector & $\mathbf{C O}_{2}$ (Fuel Combustion) & $\mathbf{C O}_{2}$ (Industrial Processes) & $\mathbf{C H}_{\mathbf{4}}$ & $\mathbf{N}_{\mathbf{2}} \mathbf{O}$ & $\mathbf{G H G s}$ \\
\hline 1 & 107.6 & 1832.6 & 3.50 & 1943.7 \\
2 & 90.7 & 2035.5 & 0.01 & 2126.2 \\
3 & 47.0 & 76.6 & 0.00 & 123.6 \\
4 & 9.1 & 0.7 & 0.00 & 9.8 \\
5 & 9.3 & 0.2 & 0.00 & 9.5 \\
6 & 46.9 & & 65.4 & 0.00 & 112.3 \\
7 & 31.9 & & 28.3 & 0.00 & 60.2 \\
8 & 7.1 & 5.8 & 0.00 & 12.9 \\
9 & 7.2 & & 0.3 & 0.00 & 7.5 \\
10 & 31.7 & 40.9 & 0.00 & 72.6 \\
11 & 144.6 & 105.8 & 4.2 & 0.01 & 148.8 \\
12 & 237.0 & 683.9 & 19.1 & 0.41 & 362.3 \\
13 & 342.9 & 808.4 & 1.1 & 0.03 & 1028.0 \\
14 & 223.6 & & 3.5 & 0.02 & 1035.5 \\
15 & 10.7 & & 0.4 & 0.00 & 11.1 \\
16 & 39.0 & & 0.5 & 0.00 & 39.5 \\
17 & 18.2 & & 0.4 & 0.00 & 18.6 \\
18 & 6.5 & & 0.2 & 0.00 & 6.7 \\
19 & 6.0 & & 0.6 & 0.00 & 6.6 \\
\hline
\end{tabular}


Table 3. Cont.

\begin{tabular}{cccccc}
\hline Sector & $\mathbf{C O}_{2}$ (Fuel Combustion) & $\mathbf{C O}_{2}$ (Industrial Processes) & $\mathbf{C H}_{\mathbf{4}}$ & $\mathbf{N}_{2} \mathbf{O}$ & $\mathbf{G H G s}$ \\
\hline 20 & 0.9 & 0.1 & 0.00 & 1.0 \\
21 & 6.3 & 0.6 & 0.00 & 6.9 \\
22 & 2736.9 & 4.5 & 0.23 & 2741.7 \\
23 & 50.0 & 50.6 & 0.00 & 100.6 \\
24 & 388.1 & 35.9 & 0.02 & 424.1 \\
25 & 53.9 & 35.2 & 0.00 & 89.1 \\
26 & 73.1 & 85.7 & 0.00 & 158.8 \\
Total & 4726.3 & 1598.1 & 4328.8 & 4.25 & $10,657.5$ \\
\hline
\end{tabular}

As to the $\mathrm{CO}_{2}$ emissions, direct emission of Sector 22 (Electric Power/Steam and Hot Water Production and Supply) amounts to $2736.9 \mathrm{Mt}$, up to $43.3 \%$ of the total, followed by those of Sector 14 (Smelting and Pressing of Ferrous and Nonferrous Metals) and Sector 13 (Nonmetal Mineral Products), accounting for $16.3 \%$ and $16.2 \%$, respectively. Sector 2 (Coal Mining and Dressing) accounts for $47.0 \%$ of the total $\mathrm{CH}_{4}$ emissions, followed by Sector 1 (Agriculture) for $42.3 \%$. Sector 1 (Agriculture) is also the leading $\mathrm{N}_{2} \mathrm{O}$ emission sector, accounting for $82.4 \%$ of the total $\mathrm{N}_{2} \mathrm{O}$ emissions, followed by Sector 12 (Chemical Products Related Industry) for 9.6\%, and Sector 22 for $5.4 \%$.

In total the five sectors numbered $1,2,13,14$ and 22 are responsible for $83.3 \%$ of the total GHG emissions. Among these five sectors, Sector 22 is the largest emitter, with $25.7 \%$ of the total GHG emissions, mainly due to massive $\mathrm{CO}_{2}$ emissions from coal combustion to produce electricity. Owing to their massive $\mathrm{CH}_{4}$ emissions and the higher GTP 115.51 in comparison with 1 to $\mathrm{CO}_{2}$, Sectors 1 and 2 contribute $18.2 \%$ and $20.0 \%$ of the total GHG emissions, respectively. Owing to massive $\mathrm{CO}_{2}$ emissions from industrial processes, Sector 14 and Sector 13 contribute $9.7 \%$ and $9.6 \%$ of the total GHG emissions, respectively.

Direct emission intensity indicates the direct emission per RMB Yuan of industrial output. As shown in Figure 1, the direct GHG emission intensity of Sector 2 (2204.5 $\mathrm{g} \mathrm{CO}_{2}$-eq/Yuan) is much larger than those of the other sectors, owing to its high $\mathrm{CH}_{4}$ emission intensity. Prominently, $\mathrm{CO}_{2}$ emissions from fuel combustion dominate the direct GHG emission intensity of Sector 22, which has a direct emission intensity of $870.8 \mathrm{~g} \mathrm{CO}_{2}$-eq/Yuan, only less than that of Sector 2 . Sector 13 represents another pattern for high direct $\mathrm{GHG}$ emission intensity due to its massive $\mathrm{CO}_{2}$ emissions from industrial processes, with a direct GHG emission intensity of $450.8 \mathrm{~g} \mathrm{CO}_{2}$-eq/Yuan. $\mathrm{CH}_{4}$ emissions are the main emission type in Sector 1, which has a direct GHG emission intensity of $397.5 \mathrm{~g}$ $\mathrm{CO}_{2}$-eq/Yuan. 
Figure 1. Direct GHG emission intensities by emission type.

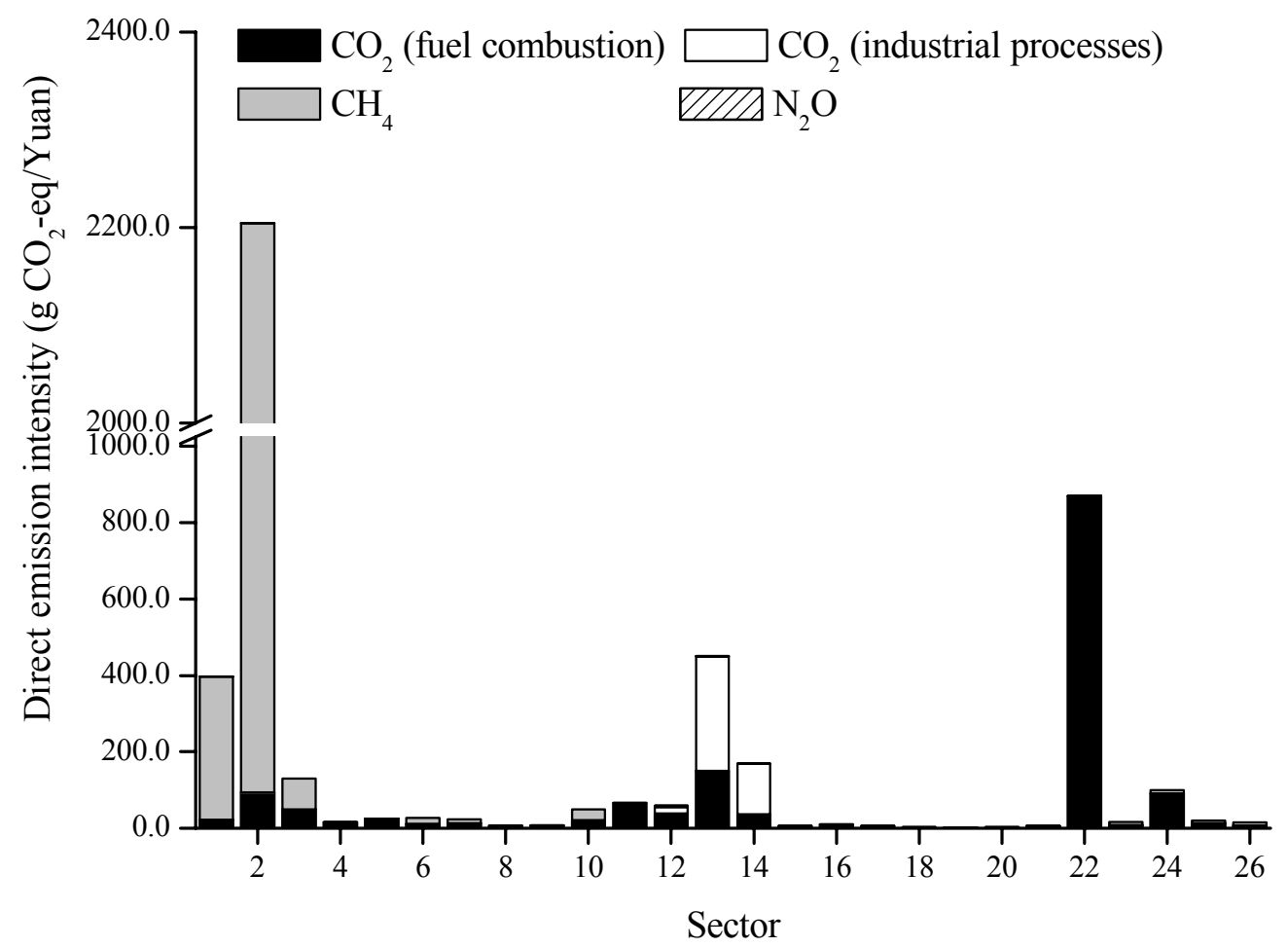

\section{Embodied GHG Emissions}

\subsection{Embodied Emission Intensities}

As shown in Figure 2 for the embodied GHG emission intensities of the 26 sectors in Chinese economy 2007, Sector 2 (Coal Mining and Dressing) holds the top volume of $2781.5 \mathrm{~g} \mathrm{CO}_{2}$-eq/Yuan (mainly owing to the high direct emission intensity), followed by Sector 22 (Electric Power/Steam and Hot Water Production and Supply) and Sector 13 (Nonmetal Mineral Products) of 1974.7 and $1095.4 \mathrm{~g} \mathrm{CO}_{2}$-eq/Yuan, respectively, with comparable direct and indirect emission intensities. For all the other sectors except Sector 1, the direct intensity is notably less than the indirect intensity. More evidently, for the 17 sectors numbered 4-10,15-21, 23, 25 and 26, the embodied intensity is basically induced by indirect emissions due to inter-industrial input, with no remarkable direct emissions. Therefore, the picture of systems embodied emissions as reflected by the input-output model is quite different from that of the direct end emissions [3,6].

The embodied GHG emission intensity can be further divided by the emission type. Figure 3 further presents the emission component of the embodied GHG emission intensity by sector. $\mathrm{CO}_{2}$ emissions from fuel combustion comprise about one half of GHG emissions in most manufacturing and service sectors. The shares of $\mathrm{CO}_{2}$ emission (fuel combustion) intensities are especially high in Sectors 3-5, 22 and 24. $\mathrm{CO}_{2}$ emissions from industrial processes share important proportions in some manufacturing industries such as Sectors 13, 14 and 23. In contrast, non- $\mathrm{CO}_{2}$ emissions account for about $40 \%-60 \%$ of the total GHG emission intensities in Sectors 1, 2, 6-12, 25 and 26. Embodied GHG emission intensities of Sectors 1, 2 and 6 are dominated by the embodied $\mathrm{CH}_{4}$ emission intensity. 
Figure 2. Embodied (direct plus indirect) GHG emission intensity by sector.

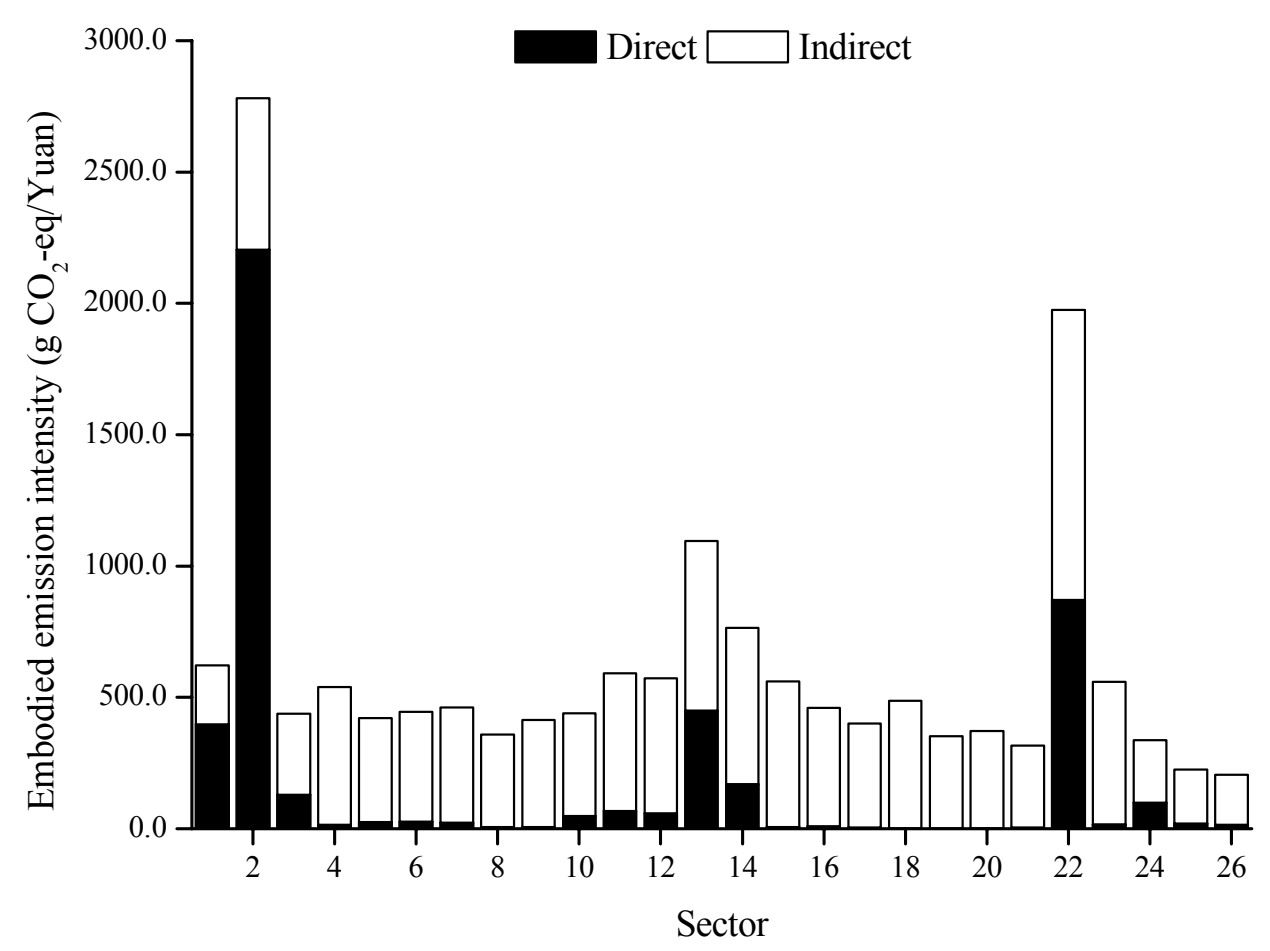

Figure 3. Emission component of the embodied GHG emission intensity by sector.

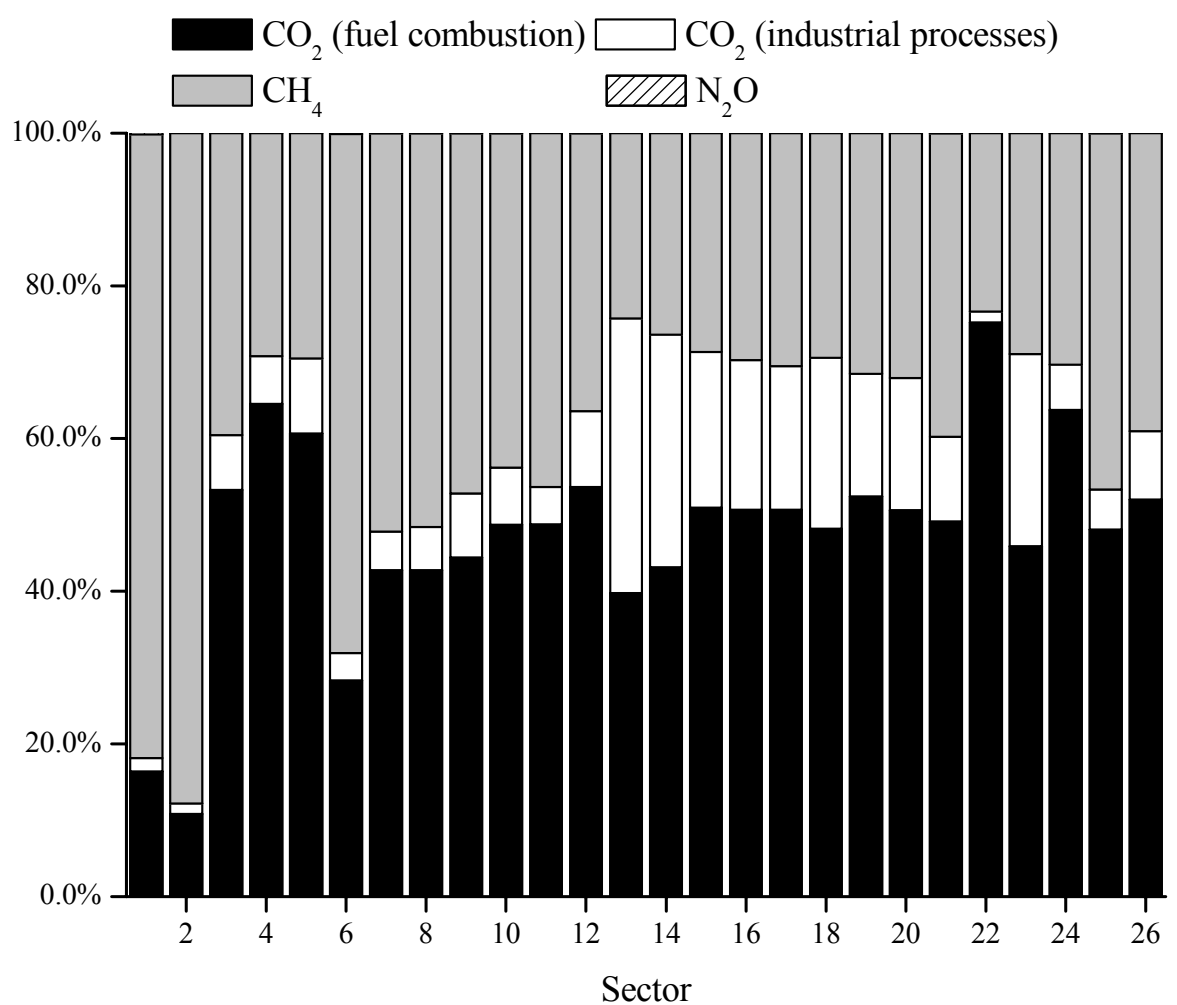


Figure 4. Contribution of direct $\mathrm{CH}_{4}$ emissions from coal mining in Sector 2 and $\mathrm{CO}_{2}$ emissions from fuel combustion in Sector 22 to the embodied GHG emission intensity by sector.

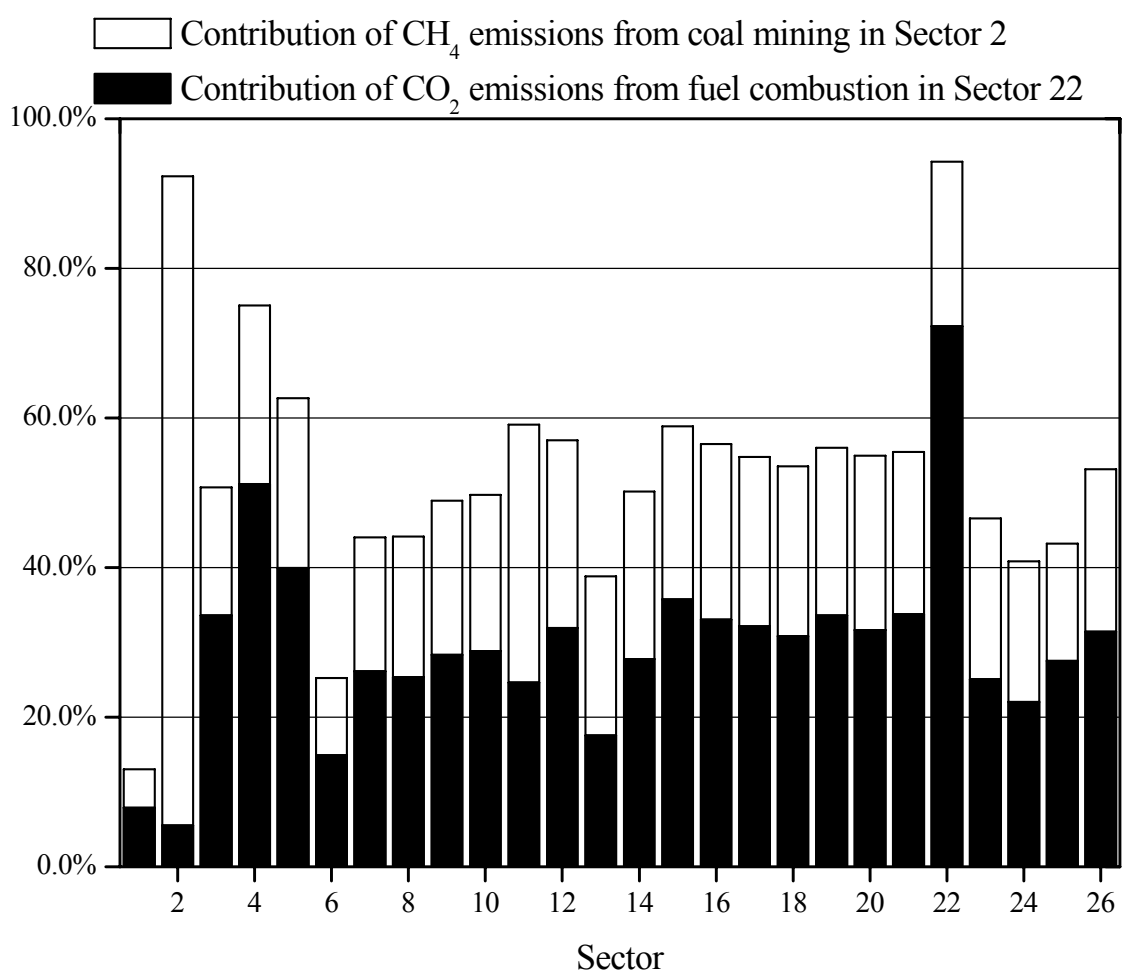

Figure 4 shows the contribution of the direct $\mathrm{CH}_{4}$ emissions from coal mining in Sector 2 (Coal Mining and Dressing) and $\mathrm{CO}_{2}$ emissions from fuel combustion in Sector 22 (Electric Power/Steam and Hot Water Production and Supply) to the embodied GHG emission intensity by sector. Around $40-60 \%$ of the embodied GHG emission intensities of most manufacturing and service sectors can be derived from these direct emissions. This is due to China's coal-dominated energy structure and coal-dominated electricity system. In $2007,69.5 \%$ of total energy use and $82.9 \%$ of total electricity output are coal based [49]. Therefore, a large fraction of embodied emissions in final demand sources from coal-consumption economy in China.

\subsection{Emissions Embodied in Final Consumption}

The total GHG emission embodied in domestic production (EEP) and that embodied in domestic consumption (EEC) are accounted as 10,657.5 and 9840.6 $\mathrm{Mt} \mathrm{CO}_{2}$-eq, respectively. The EEP exceeds the EEC by $8.3 \%$. As shown in Figure 5 for the distribution of GHG emissions embodied in domestic consumption (EEC), Sector 23 (Construction) holds the top embodied GHG emission. China's rapidly expanding infrastructure construction has a significant impact on embodied GHG emissions, as construction activities need a great deal of direct and indirect industrial inputs (e.g., cement, electricity and metal products). Jiang and Tovey [50] reported that the direct and indirect embedded energy use by China's building sector accounts for about one quarter of the total energy use in China. Other sectors such as Sector 26 (Other Service Activities), Sector 1 (Agriculture), Sector 6 (Food Processing, Food Production, Beverage Production, and Tobacco Processing), Sector 16 (Ordinary Machinery, 
Equipment for Special Purpose), and Sector 17 (Transportation Equipment), which have prominent peaks on emissions embodied in both domestic production and domestic consumption, are either directly involved in manufacturing and processing of raw materials or major consumers of industrial products. Particularly, Sectors 1 and 6 show massive embodied $\mathrm{CH}_{4}$ emissions due to the increased grain and meat production to meet the rising standard of living level and westernized lifestyle in China's households [3].

Figure 5. GHG emissions embodied in domestic consumption (EEC) by sector.

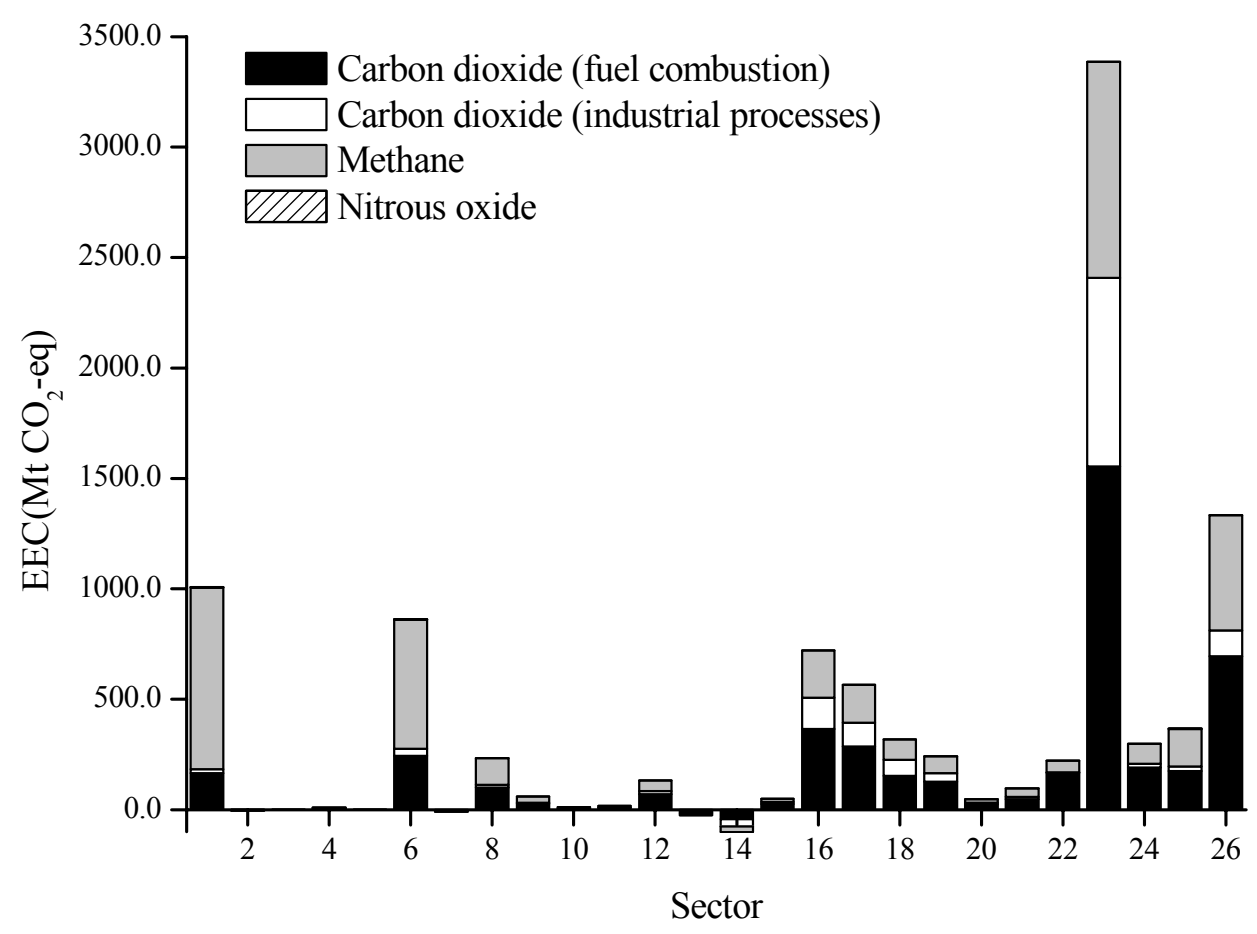

Table 4 illustrates the economy-wide balance of monetary flows, GHG emissions, $\mathrm{CO}_{2}$ emissions, and $\mathrm{CH}_{4}$ emissions. In the whole, household consumption is responsible for $27.5 \%$ of the total GHG emission embodied in the final demand. The embodied GHG emission in urban consumption is 2.7 times of that in rural consumption. It is noted that rural and urban consumptions are $\mathrm{CH}_{4}$ emission intensive. The $\mathrm{CH}_{4}$ emissions comprise $57.3 \%$ of the total embodied GHG emission for the rural consumption and $48.6 \%$ for the urban consumption. This can be explained by the main consumption of agricultural products and foodstuff in households.

Prominently, gross capital formation is responsible for $39.0 \%$ and $44.3 \%$ of the total $\mathrm{GHG}$ and $\mathrm{CO}_{2}$ emission embodied in final demand, respectively, larger than other final demand categories. Weber et al. [12] estimated that capital investment was responsible for $37 \%$ of China's $\mathrm{CO}_{2}$ emissions in 2005. From the three components of GDP by expenditure approach during 2001-2007 (Table 5) [49], two economic components (final consumption expenditure and gross capital formation) shared the majority proportion of the GDP. China has now one of the highest investment rates in the world with the gross capital formation rate in GDP keeping on about $42 \%$ in recent years. Capital investments such as in manufacturing, infrastructure, and real estate related sectors have become an important motor for economic growth [8,49], which result in increasing embodied GHG emissions through the demand of electricity, cement, steel, nonferrous metals, etc. Among different final use categories, the 
shares of imports, gross capital formation and exports in GHG emissions are higher than those in monetary flows, as shown in Table 4, due to the higher emission embodiment.

Table 4. Economy-wide balance of monetary and emission flows.

\begin{tabular}{ccccccccc}
\hline & \multicolumn{2}{c}{ Money } & \multicolumn{2}{c}{ GHG } & \multicolumn{2}{c}{$\mathbf{C O}_{\mathbf{2}}$} & \multicolumn{2}{c}{$\mathbf{C H}_{\mathbf{4}}$} \\
\cline { 2 - 10 } & $\mathbf{1 0}^{4}$ Yuan & $\begin{array}{c}\text { Fraction } \\
(\%)\end{array}$ & $\begin{array}{c}\text { Mt } \\
\mathbf{C O}_{2} \text {-eq }\end{array}$ & $\begin{array}{c}\text { Fraction } \\
(\%)\end{array}$ & Mt & $\begin{array}{c}\text { Fraction } \\
(\%)\end{array}$ & $\begin{array}{c}\text { Mt } \\
\mathbf{C O}_{2} \text {-eq }\end{array}$ & $\begin{array}{c}\text { Fracti } \\
\text { on (\%) }\end{array}$ \\
\hline Total Production & & & & & & & & \\
\hline Domestic (GDP) & $2.7 \times 10^{9}$ & 78.2 & 10657.5 & 75.7 & 6324.4 & 74.6 & 4328.9 & 77.5 \\
Import & $7.4 \times 10^{8}$ & 21.8 & 3415.9 & 24.3 & 2159.0 & 25.4 & 1256.0 & 22.5 \\
Total & $3.4 \times 10^{9}$ & 100.0 & 14073.5 & 100.0 & 8483.4 & 100.0 & 5584.9 & 100.0 \\
\hline Final Demand & & & & & & & & \\
\hline Rural & $2.4 \times 10^{8}$ & 7.2 & 1045.9 & 7.4 & 445.3 & 5.2 & 599.8 & 10.7 \\
Urban & $7.2 \times 10^{8}$ & 21.2 & 2831.0 & 20.1 & 1454.2 & 17.1 & 1375.1 & 24.6 \\
Government & $3.5 \times 10^{8}$ & 10.4 & 761.1 & 5.4 & 459.7 & 5.4 & 301.2 & 5.4 \\
Gross capital & $1.1 \times 10^{9}$ & 32.6 & 5484.1 & 39.0 & 3758.4 & 44.3 & 1724.7 & 30.9 \\
formation & & & & & & & & \\
Exports & $9.6 \times 10^{8}$ & 28.1 & 4232.9 & 30.1 & 2663.3 & 31.4 & 1568.3 & 28.1 \\
Others & $1.9 \times 10^{7}$ & 0.6 & -281.4 & -2.0 & -297.5 & -3.5 & 15.8 & 0.3 \\
Total & $3.4 \times 10^{9}$ & 100.0 & 14073.5 & 100.0 & 8483.4 & 100.0 & 5584.9 & 100.0 \\
\hline
\end{tabular}

Table 5. Gross domestic product (GDP) by expenditure approach.

\begin{tabular}{ccccc}
\hline Year & $\begin{array}{c}\text { GDP (Billion } \\
\text { Yuan) }\end{array}$ & $\begin{array}{c}\text { Gross Capital } \\
\text { Formation Rate (\%) }\end{array}$ & $\begin{array}{c}\text { Final Consumption } \\
\text { Rate (\%) }\end{array}$ & $\begin{array}{c}\text { Net Exports of Goods and } \\
\text { Services Rate (\%) }\end{array}$ \\
\hline 2001 & $10,897.2$ & 36.49 & 61.37 & 2.13 \\
2002 & $12,035.0$ & 37.86 & 59.57 & 2.57 \\
2003 & $13,639.9$ & 41.03 & 56.78 & 2.19 \\
2004 & $16,028.0$ & 43.15 & 54.30 & 2.54 \\
2005 & $18,869.2$ & 42.74 & 51.84 & 5.42 \\
2006 & $22,165.1$ & 42.59 & 49.90 & 7.51 \\
2007 & $26,324.3$ & 42.33 & 48.79 & 8.88 \\
\hline
\end{tabular}

Note: Gross capital formation rate refers to gross capital formation as percentage of gross domestic product by expenditure approach; final consumption rate refers to final consumption expenditures as percentage of gross domestic product by expenditure approach.

\subsection{Emissions Embodied in International Trade}

As shown in Figure 6, the GHG emission embodied in China's exports (EEE) is calculated as 4232.9 $\mathrm{Mt} \mathrm{CO}_{2}$-eq, in magnitude up to $39.7 \%$ of the total direct domestic emission. Of the total EEE, $47.8 \%$ is due to the $\mathrm{CO}_{2}$ emission from fuel combustion $(2021.7 \mathrm{Mt}), 37.1 \%$ due to the $\mathrm{CH}_{4}$ emission, and $15.1 \%$ due to the $\mathrm{CO}_{2}$ emission from industrial processes. Meanwhile, China also avoids emitting 3416.0 $\mathrm{Mt} \mathrm{CO}_{2}$-eq GHGs (EAI or EEI in this paper) as a result of importing goods from the rest of the world. As a net exporter of embodied GHG emissions, the net embodied GHG emission of international trade balance (EEB) is around $816.9 \mathrm{Mt} \mathrm{CO}_{2}$-eq. 
Figure 6. GHG emissions embodied in production, consumption and international trade.

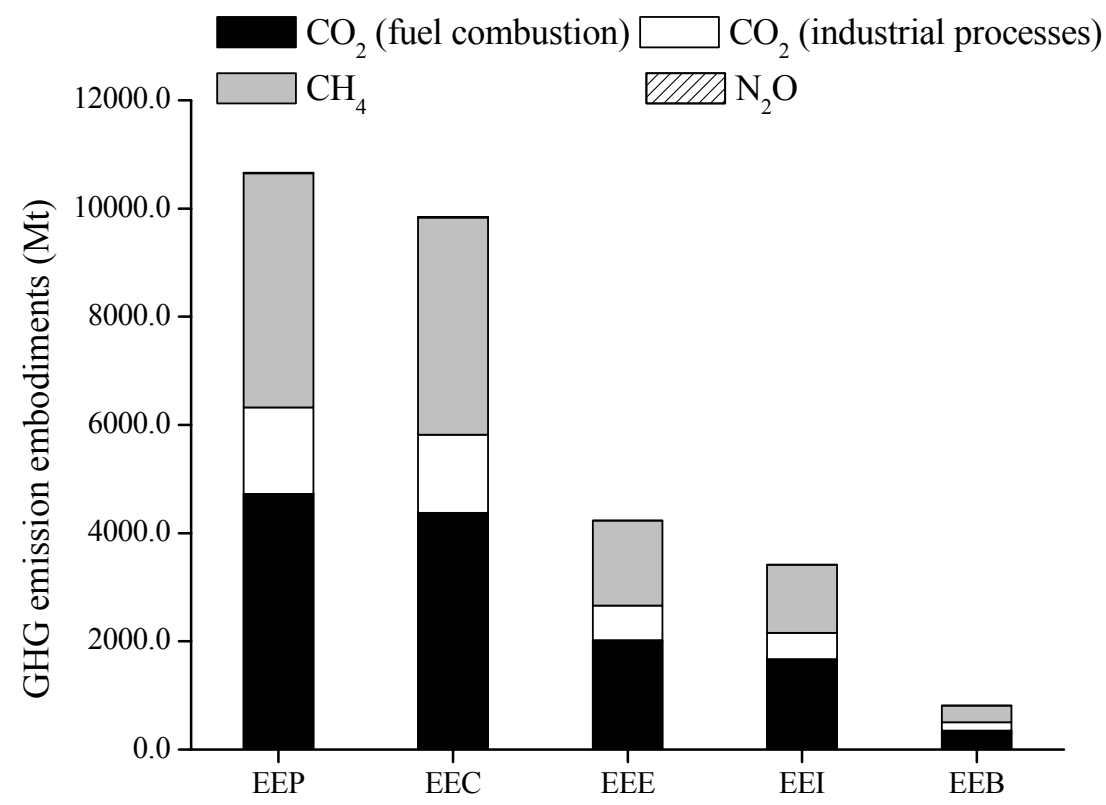

Many authors have addressed the fact that the assumptions regarding the emissions of imports can potentially have a significant impact on the estimate of emission embodiment [51,52]. Since the calculation of the GHG emissions embodied in import is based on the assumptions that the imported products have the same emission intensities as those produced in China, it may result in the volume of the real GHG emissions embodied in import (EEI) lower than the result calculated from above assumption. In fact, Chinese industry has the greater relative carbon intensity, through its greater use of coal and less efficient manufacturing methods compared with the trade partners [53-56]. The quantity of embodied GHG emissions in China is greater than the embodied emissions required to manufacture the same goods in the imported countries. According to Yan and Yang [56], $\mathrm{CO}_{2}$ emissions embodied in China's export were 2.9 times of that embodied in China's import by using American domestic emission factors for the imports. Using the estimated emission factor for each country, OECD [51] derived that the emissions embodied in China's exports were about 4.5 times of those embodied in China's imports in 1997. Peters and Hertwich [57] and Lin and Sun [58] reported that using individual emission factors of the importers, the $\mathrm{CO}_{2}$ emissions embodied in China's imports would be around four times lower than using China's domestic emission factors. With a relatively high domestic GHG emissions factor in China, actually, net embodied GHG emissions of China's trade balance (EEB) should be larger than the calculated result in this study.

On the sectoral basis, Table 6 shows the distribution of GHG emissions embodied in exports (EEE) and imports (EEI) by sector. The largest GHGs-export sector is Sector 19 (Electronic and Telecommunications Equipment) with $17.8 \%$ of the total EEE, followed by Sector 12 (Chemical Products Related Industry, 9.8\%), Sector 14 (Smelting and Pressing of Ferrous and Nonferrous Metals, 9.3\% of the total), Sector 7 (Textile, 9.0\%), Sector 18 (Electric Equipment and Machinery, $7.9 \%$ ), and other manufacturing industries. As to the distribution of the net embodied GHG emission of international trade balance (EEB) by sector, Sector 7 is the largest net embodied GHG-export sector, accounting for $41.8 \%$ of the total EEB, followed by Sector 8 (Garments and Other Fiber Products, 
Leather, Furs, Down and Related Products, 22.3\%), Sector 19 (21.9\%), Sector 15 (Metal Products, 20.5\%), Sector 18 (20.2\%), and Sector 13 (14.8\%). In contrast, Sector 3 (Petroleum and Natural Gas Extraction) and Sector 4 (Ferrous and Nonferrous Metals Mining and Dressing) are the top two sectors of net embodied GHG emission importers. It is well known that the total domestic outputs of crude oil, iron ore and some other materials in China cannot satisfy the domestic production demand.

Table 6. Distribution of embodied GHG emissions in international trade by sector.

\begin{tabular}{|c|c|c|c|c|c|}
\hline \multirow[b]{2}{*}{ Sector } & \multicolumn{2}{|l|}{ EEE } & \multicolumn{2}{|l|}{ EEI } & \multirow{2}{*}{$\begin{array}{c}\text { EEB } \\
\text { Emission } \\
\text { Embodiment } \\
\left(\mathrm{Mt} \mathrm{CO}_{2} \text {-eq) }\right.\end{array}$} \\
\hline & $\begin{array}{c}\text { Emission } \\
\text { Embodiment } \\
\left(\mathrm{Mt} \mathrm{CO}_{2}-\mathrm{eq}\right) \\
\end{array}$ & Fraction & $\begin{array}{c}\text { Emission } \\
\text { Embodiment } \\
\left(\mathrm{Mt} \mathrm{CO}_{2} \text {-eq }\right)\end{array}$ & Fraction & \\
\hline 1 & 41.4 & $1.0 \%$ & 144.8 & $4.2 \%$ & -103.4 \\
\hline 2 & 65.0 & $1.5 \%$ & 53.5 & $1.6 \%$ & 11.6 \\
\hline 3 & 7.6 & $0.2 \%$ & 252.9 & $7.4 \%$ & -245.3 \\
\hline 4 & 4.4 & $0.1 \%$ & 219.8 & $6.4 \%$ & -215.4 \\
\hline 5 & 6.3 & $0.2 \%$ & 12.7 & $0.4 \%$ & -6.3 \\
\hline 6 & 85.0 & $2.0 \%$ & 70.3 & $2.1 \%$ & 14.7 \\
\hline 7 & 379.0 & $9.0 \%$ & 37.7 & $1.1 \%$ & 341.3 \\
\hline 8 & 203.9 & $4.8 \%$ & 21.9 & $0.6 \%$ & 182.0 \\
\hline 9 & 100.5 & $2.4 \%$ & 11.2 & $0.3 \%$ & 89.3 \\
\hline 10 & 99.6 & $2.4 \%$ & 36.4 & $1.1 \%$ & 63.2 \\
\hline 11 & 45.4 & $1.1 \%$ & 85.8 & $2.5 \%$ & -40.4 \\
\hline 12 & 415.3 & $9.8 \%$ & 522.4 & $15.3 \%$ & -107.1 \\
\hline 13 & 162.5 & $3.8 \%$ & 41.3 & $1.2 \%$ & 121.2 \\
\hline 14 & 394.9 & $9.3 \%$ & 330.9 & $9.7 \%$ & 64.0 \\
\hline 15 & 200.0 & $4.7 \%$ & 32.9 & $1.0 \%$ & 167.2 \\
\hline 16 & 264.2 & $6.2 \%$ & 324.4 & $9.5 \%$ & -60.2 \\
\hline 17 & 131.8 & $3.1 \%$ & 120.6 & $3.5 \%$ & 11.2 \\
\hline 18 & 332.5 & $7.9 \%$ & 167.3 & $4.9 \%$ & 165.2 \\
\hline 19 & 752.7 & $17.8 \%$ & 573.8 & $16.8 \%$ & 178.8 \\
\hline 20 & 120.7 & $2.9 \%$ & 146.5 & $4.3 \%$ & -25.8 \\
\hline 21 & 42.6 & $1.0 \%$ & 51.7 & $1.5 \%$ & -9.2 \\
\hline 22 & 12.9 & $0.3 \%$ & 3.6 & $0.1 \%$ & 9.3 \\
\hline 23 & 22.9 & $0.5 \%$ & 12.4 & $0.4 \%$ & 10.5 \\
\hline 24 & 151.1 & $3.6 \%$ & 50.7 & $1.5 \%$ & 100.4 \\
\hline 25 & 107.2 & $2.5 \%$ & 11.8 & $0.4 \%$ & 95.4 \\
\hline 26 & 83.4 & $2.0 \%$ & 78.4 & $2.3 \%$ & 5.0 \\
\hline
\end{tabular}

\section{Conclusions}

To understand the full context to achieve GHG emission mitigation, embodiment analyses from different angles of view are an important step in evaluating the complex interactions and the likely impact of the whole process on the social network and addressing the mitigation potential of GHG emissions at different points in the socio-economic system before meaningful strategies are recommended. In this paper, considering the Global Thermodynamic Potential indicator to perform a 
unified GTP-based assessment of GHG emissions provides a new insight to examine the results of GHG emission embodiment for China. The major conclusions are as follows:

(1) The estimated total direct GHG emissions by the Chinese economy in 2007 amount to 10,657.5 $\mathrm{Mt} \mathrm{CO}_{2}$-eq by the Global Thermodynamic Potentials with $40.6 \%$ from $\mathrm{CH}_{4}$ emissions in magnitude of the same importance as $\mathrm{CO}_{2}$ emissions. On a sectoral basis, the five primary sectors of the Electric Power/Steam and Hot Water Production and Supply, Coal Mining and Dressing, Agriculture, Smelting and Pressing of Ferrous and Nonferrous Metals, and Nonmetal Mineral Products are responsible for $83.3 \%$ of the total GHG emissions with different GHG emission structures.

(2) The demands of coal and coal-electricity determine the structure of emission embodiment to an essential extent. Embodied GHG emission intensities in most manufacturing and service sectors are highly related to the direct $\mathrm{CH}_{4}$ emissions from coal mining in the Coal Mining and Dressing sector and $\mathrm{CO}_{2}$ emissions from fuel combustion in the Electric Power/Steam and Hot Water Production and Supply sector. The Construction sector holds the top GHG emissions embodied in both domestic production and domestic consumption. Household consumption which is $\mathrm{CH}_{4}$ emission intensive to some extent is responsible for $27.5 \%$ of the total GHG emission embodied in the final demand. However, the GHG emission embodied in gross capital formation is the largest in the final demand categories. Extensive investment and limited consumption by Chinese economy can be partly reflected by the profile of GHG emission embodiment.

(3) China is a net exporter of embodied GHG emissions, with a remarkable share of direct emission induced by international trade. The amount of GHG emissions embodied in China's exports (EEE) is equal to $39.7 \%$ of the total direct domestic emission. Of the total EEE, $47.8 \%$ is due to the $\mathrm{CO}_{2}$ emission from fuel combustion, $37.1 \%$ due to $\mathrm{CH}_{4}$ emission, and $15.1 \%$ due to the $\mathrm{CO}_{2}$ emissions from industrial processes. China also avoids emitting $3416.0 \mathrm{Mt} \mathrm{CO}_{2}$-eq GHGs as a result of importing goods from the rest of the World. In international trade balance, China's textile products, industrial raw materials, and primary machinery and equipment products exports have a significant impact on embodied GHG emissions.

(4) Although the main conclusions of GHG emission embodiment based on Global Thermodynamic Potential (GTP) equivalent are similar to those based on Global Warming Potential (GWP) equivalent, $\mathrm{CH}_{4}$ emissions based on GTP equivalent have remarkable influence in the structure of embodied GHG emissions in the final demand. For instance, $\mathrm{CH}_{4}$ emissions comprise $57.3 \%, 48.6 \%, 39.6 \%, 31.4 \%$ and $37.1 \%$ of the total embodied GHG emission for the rural consumption, urban consumption, government consumption, gross capital formation, and exports, respectively, much greater than corresponding fractions calculated based on the GWP in [3]. These results highlight the importance of $\mathrm{CH}_{4}$ emissions for the case of China and indicate the essential effect of $\mathrm{CH}_{4}$ emissions on global climate change. 


\section{Acknowledgments}

This study has been supported by the Foundation of State Key Laboratory of Coal Resources and Safe Mining, China University of Mining \& Technology (Grant No. SKLCRSM10KFA06) and in part by the National Natural Science Foundation (Grant No. 70903005). Very helpful comments by the editor and three anonymous reviewers are highly appreciated.

\section{References}

1. International Energy Agency (IEA). $\mathrm{CO}_{2}$ Emissions from Fuel Combustion 2009—Highlights, 2009. Available online: http:/www.iea.org/co2highlights/co2highlights.pdf (accessed on 3 May 2010).

2. Zhang, Z.X. China in the transition to a low-carbon economy. Energy Policy 2010, 38, 6638-6653.

3. Chen, G.Q.; Zhang, B. Greenhouse gas emissions in China 2007: Inventories and input-output analysis. Energy Policy 2010, 38, 6180-6193.

4. Wiedmann, T.; Lenzen, M.; Turner, K.; Barrett, J. Examining the global environmental impact of regional consumption activities-Part 2: Review of input-output models for the assessment of environmental impacts embodied in trade. Ecol. Econ. 2007, 61, 15-26.

5. Miller, R.E.; Blair, P.D. Input-Output Analysis: Foundations and Extensions, 2nd ed.; Cambridge University Press: London, UK, 2009.

6. Wiedmann, T. A review of recent multi-region input-output models used for consumption-based emission and resource accounting. Ecol. Econ. 2009, 69, 211-222.

7. Shui, B.; Harriss, R.C. The role of $\mathrm{CO}_{2}$ embodiment in US-China trade. Energy Policy 2006, 34, 4063-4068.

8. Peters, G.P.; Weber, C.L.; Guan, D.; Hubacek, K. China's growing $\mathrm{CO}_{2}$ emissions-A race between lifestyle changes and efficiency gains. Environ. Sci. Technol. 2007, 41, 5939-5944.

9. Wang, T.; Watson, J. Who Owns China's Carbon Emissions? Tyndall Centre for Climate Change Research: Sussex, UK, 2007.

10. Pan, J.H.; Phillips, J.; Chen, Y. China's balance of emissions embodied in trade: Approaches to measurement and allocating international responsibility. Oxf. Rev. Econ. Policy 2008, 24, 354-376.

11. Guan, D.; Hubacek, K.; Weber, C.L.; Peters, G.P.; Reiner, D. The drivers of Chinese $\mathrm{CO}_{2}$ emissions from 1980 to 2030. Glob. Environ. Change Hum. Policy Dimens. 2008, 18, 626-634.

12. Weber, C.L.; Peters, G.P.; Guan, D.; Hubacek, K. The contribution of Chinese exports to climate change. Energy Policy 2008, 36, 3572-3577.

13. Guan, D.; Peters, G.P.; Weber, C.L.; Hubacek, K. Journey to world top emitter: An analysis of the driving forces of China's recent $\mathrm{CO}_{2}$ emissions surge. Geophys. Res. Lett. 2009, 36, L04709, doi:10.1029/2008GL036540.

14. Zhang, Y. Supply-side structural effect on carbon emissions in China. Energy Econ. 2010, 32, 186-193.

15. Liu, X.; Ishikawab, M.; Wang, C.; Dong, Y.; Liu, W. Analyses of $\mathrm{CO}_{2}$ emissions embodied in Japan-China trade. Energy Policy 2010, 38, 1510-1518. 
16. Chen, Z.M.; Chen, G.Q. Embodied carbon dioxide emission at supra-national scale: A coalition analysis for G7, BRIC, and the rest of the world. Energy Policy 2011, 39, 2899-2909.

17. INCCCC. Initial National Communication on Climate Change of China, 2004. Available online: http://www.ccchina.gov.cn/file/en_source/da/da2004110901.pdf (accessed on 5 April 2011).

18. Zhang, B.; Chen, G.Q. Methane emissions by Chinese economy: Inventory and embodiment analysis. Energy Policy 2010, 38, 4304-4316.

19. Zhou, J.B. Embodied Ecological Elements Accounting of National Economy. Ph.D. Dissertation, Peking University, Beijing, China, 2008, (in Chinese).

20. Chen, Z.M.; Chen, G.Q.; Zhou, J.B.; Jiang, M.M.; Chen, B. Ecological input-output modeling for embodied resources and emissions in Chinese economy 2005. Commun. Nonlinear Sci. Numer. Simul. 2010, 15, 1942-1965.

21. Chen, G.Q.; Chen, Z.M. Carbon emissions and resources use by Chinese economy 2007: A 135-sector inventory and input-output embodiment. Commun. Nonlinear Sci. Numer. Simul. 2010, 15, 2647-2732.

22. Chen, G.Q.; Chen, Z.M. Greenhouse gas emissions and natural resources use by the world economy: Ecological input-output modeling. Ecol. Model. 2011, 222, 2362-2376.

23. IPCC. IPCC Fourth Assessment Report: Climate Change 2007 (AR4), 2007. Available online: http://www.ipcc.ch/publications_and_data/publications_and_data_reports.htm (accessed on 22 February 2011).

24. Wall, G. Exergy-A Useful Concept within Resource Accounting, Research Report No. 77-42; Institute of Theoretical Physics: Goteborg, Sweden, 1977.

25. Rosen, M.A.; Dincer, I. Exergy analysis of waste emissions. Int. J. Energy Res. 1999, 23, $1153-1163$.

26. Wall, G.; Gong, M. On exergy and sustainable development—Part 1: Conditions and concepts. Exergy Int. J. 2001, 1, 128-145.

27. Rosen, M.A.; Dincer, I. Exergy as the confluence of energy, environment and sustainable development. Exergy Int. J. 2001, 1, 3-13.

28. Szargut, J. Exergy Method: Technical and Ecological Applications; WIT Press: Southampton, UK, 2005.

29. Chen, G.Q. Scarcity of exergy and ecological evaluation based on embodied exergy. Commun. Nonlinear Sci. Numer. Simul. 2006, 11, 531-552.

30. Gasparatos, A.; El-Haram, M.; Horner, M. A longitudinal analysis of the UK transport sector, 1970-2010. Energy Policy 2009, 37, 623-632.

31. Ometto, A.; Roma, W.N.L. Atmospheric impacts of the life cycle emissions of fuel ethanol in Brazil: Based on chemical exergy. J. Clean. Prod. 2010, 18, 71-76.

32. Chen, B.; Chen, G.Q. Ecological footprint accounting and analysis of the Chinese Society 1981-2001 based on embodied exergy. Ecol. Econ. 2007, 61, 355-376.

33. Gong, M.; Wall, G. On exergy and sustainable development-Part 2: Indicators and methods. Exergy Int. J. 2001, 1, 217-233.

34. Ji, X.; Chen, G.Q.; Chen, B.; Jiang, M.M. Exergy-based assessment for waste gas emissions from Chinese transportation. Energy Policy 2009, 37, 2231-2240. 
35. Ayres, R.U.; Ayres, L.W.; Martinás, K. Exergy, waste accounting, and life cycle analysis. Energy 1998, 23, 355-363.

36. Rosen, M.A.; Dincer, I. On exergy and environmental impact. Int. J. Energy Res. 1997, 21, 643-654.

37. Dincer, I. The role of exergy in energy policy making. Energy Policy 2002, 30, 137-149.

38. Rosen, M.A. Assessing energy technologies and environmental impacts with the principles of thermodynamics. Appl. Energy 2002, 72, 427-441.

39. Rosen, M.A.; Dincer, I.; Kanoglu, M. Role of exergy in increasing efficiency and sustainability and reducing environmental impact. Energy Policy 2008, 36, 128-137.

40. Chen, G.Q. Exergy consumption of the earth. Ecol. Model. 2005, 184, 363-380.

41. Ji, X.; Chen, G.Q. Unified account of gas pollutants and greenhouse gas emissions: Chinese transportation 1978-2004. Commun. Nonlinear Sci. Numer. Simul. 2010, 15, 2710-2722.

42. Chen, G.Q.; Chen, B. Extended-exergy analysis of the Chinese society. Energy 2009, 34, $1127-1144$.

43. Gasparatos, A.; Ei-Haram, M.; Horner, M. Assessing the sustainability of the UK society using thermodynamic concepts: Part 2. Renew. Sustain. Energy Rev. 2009, 13, 1074-1081.

44. Zhang, B.; Chen, G.Q. Physical sustainability assessment for the China society: Exergy-based systems account for resources use and environmental emissions. Renew. Sustain. Energy Rev. 2010, 14, 1527-1545.

45. Gasparatos, A.; Ei-Haram, M.; Horner, M. A critical review of reductionist approaches for assessing the progress towards sustainability. Environ. Impact Assess. Rev. 2008, 28, 286-311.

46. Morris, D.R.; Szargut, J. Standard chemical exergy of some elements and compounds on the planet earth. Energy 1986, 11, 733-755.

47. NBS, National Bureau of Statistics. Input-Output Tables of China; China Statistic Press: Beijing, China, 2009, (in Chinese).

48. Zhang, B. Methane Emissions in China: Time Series Inventories and Systems embodiment Analysis. Ph.D. Dissertation, Peking University, Beijing, China, 2011, (in Chinese).

49. CSY. China Statistical Yearbook. National Bureau of Statistics of China, 2008. Available online: http://www.stats.gov.cn/tjsj/ndsj/2008/indexch.htm (accessed on 1 June 2011).

50. Jiang, P.; Tovey, N.K. Opportunities for low carbon sustainability in large commercial buildings in China. Energy Policy 2009, 37, 4949-4958.

51. Ahmad, N.; Wyckoff, A. Carbon Dioxide Emissions Embodied in International Trade of Goods, STI Working Paper (15); Organisation for Economic Co-operation and Development (OECD): Paris, France, 2003.

52. Lenzen, M.; Pade, L.L.; Munksgaard, J. $\mathrm{CO}_{2}$ multipliers in multi-region input-output models. Econ. Syst. Res. 2004, 16, 391-412.

53. Li, Y.; Hewitt, C.N. The effect of trade between China and the UK on national and global carbon dioxide emissions. Energy Policy 2008, 36, 1907-1914.

54. Xu, M.; Allenby, B.; Chen, W.Q. Energy and air emissions embodied in China-U.S. Trade: Eastbound assessment using adjusted bilateral trade data. Environ. Sci. Technol. 2009, 43, 3378-3384. 
55. Guo, J.; Zou, L.L.; Wei, Y.M. Impact of inter-sectoral trade on national and global $\mathrm{CO}_{2}$ emissions: An empirical analysis of China and US. Energy Policy 2010, 38, 1389-1397.

56. Yan, Y.F.; Yang, L. China's foreign trade and climate change: A case study of $\mathrm{CO}_{2}$ emissions. Energy Policy 2010, 38, 350-356.

57. Peters, G.P.; Hertwich, E.G. $\mathrm{CO}_{2}$ embodied in international trade with implications for global climate policy. Environ. Sci. Technol. 2008, 42, 1401-1407.

58. Lin, B.; Sun, C. Evaluating carbon dioxide emissions in international trade of China. Energy Policy 2010, 38, 613-621.

(C) 2011 by the authors; licensee MDPI, Basel, Switzerland. This article is an open access article distributed under the terms and conditions of the Creative Commons Attribution license (http://creativecommons.org/licenses/by/3.0/). 